Decreased Levels of Blood Trypanosome Infection Correlate with Female Expression of a Male Secondary Sexual Trait: Implications for Sexual Selection

Author(s): Jaime Potti and Santiago Merino

Source: Proceedings: Biological Sciences, Vol. 263, No. 1374 (Sep. 22, 1996), pp. 1199-1204

Published by: The Royal Society

Stable URL: http://www.jstor.org/stable/50521

Accessed: 29/09/2009 09:28

Your use of the JSTOR archive indicates your acceptance of JSTOR's Terms and Conditions of Use, available at http://www.jstor.org/page/info/about/policies/terms.jsp. JSTOR's Terms and Conditions of Use provides, in part, that unless you have obtained prior permission, you may not download an entire issue of a journal or multiple copies of articles, and you may use content in the JSTOR archive only for your personal, non-commercial use.

Please contact the publisher regarding any further use of this work. Publisher contact information may be obtained at http://www.jstor.org/action/showPublisher?publisherCode=rsl.

Each copy of any part of a JSTOR transmission must contain the same copyright notice that appears on the screen or printed page of such transmission.

JSTOR is a not-for-profit organization founded in 1995 to build trusted digital archives for scholarship. We work with the scholarly community to preserve their work and the materials they rely upon, and to build a common research platform that promotes the discovery and use of these resources. For more information about JSTOR, please contact support@ jstor.org. 


\title{
Decreased levels of blood trypanosome infection correlate with female expression of a male secondary sexual trait: implications for sexual selection
}

\author{
JAIME POTTI AND SANTIAGO MERINO \\ Departamento de Biología Animal, Universidad de Alcalá de Henares, E-28871 Alcalá de Henares (Madrid), Spain
}

\begin{abstract}
SUMMAR Y
Hamilton \& Zuk proposed that conspicuous male plumages of birds could be reliable signals of parasite resistance. We examined this prediction in a system involving blood trypanosomes in a passerine bird, the pied flycatcher (Ficedula hypoleuca). Trypanosome prevalence and intensity of infections were unrelated to male age and expression of a secondary sexual trait. However, trypanosome infections were absent or maintained at significantly lower levels in females expressing a male trait which females have been shown to prefer in males. This relation held even after controlling for the significant effects that female age had on both the expression of the male trait and the rate of parasitism by trypanosomes. Given that the male trait is heritable and genetically correlated between the sexes, and there exists assortative mating based on white patch size and/or expression, a system of mutual mate choice may exist. In such a system, the benefits accrued to both males and females would be a higher chance of successful mating and the acquisition of genes for resistance to parasites to transmit to the offspring. These data thus support by an alternate route Hamilton \& Zuk's hypothesis on parasite-driven sexual selection.
\end{abstract}

\section{INTRODUGTION}

Hamilton \& Zuk (1982) proposed that the bright plumages of male birds may have evolved to signal parasite resistance so that females choosing males with the more elaborate display structures would be picking males with genes for parasite resistance. At the intraspecific level there exists uncertainty regarding the generality of the Hamilton-Zuk prediction, as mixed evidence has been obtained in studies examining the hypothesis of increased resistance to parasites being related to more elaborate male secondary sexual traits (see Read 1988; Møller 1990a, b; Weatherhead 1990; Andersson 1994; Seutin 1994; Dufva \& Allander 1995; Sundberg 1995). One problem for testing this hypothesis within species is that the commonly observed positive relation between age and plumage brightness (Savalli 1995) may be confounded by the covariation between parasitism and host age (Potti \& Merino 1995, Thomas et al. 1995). The pied flycatcher (Ficedula hypoleuca) is a small European passerine with a high degree of plumage sexual dimorphism during the breeding season. The plumage of males varies among individuals but in general males have a conspicuously contrasting white and black plumage, while females are dull brown (Drost 1936; Lundberg \& Alatalo 1992; Cramp \& Perrins 1993). Although the significance of this variation in the realm of sexual selection has been addressed (Røskaft \& Järvi 1983; Järvi et al. 1987; Slagsvold \& Lifjeld 1988; Potti \& Montalvo 1991 a; Lundberg \& Alatalo 1992) there remains uncertainty concerning the role of overall mantle colour on sexual selection and female mate choice (but see Sætre et al. 1994). In addition, the sexes also differ in the expression of another dimorphic trait, a patch of white feathers in the forehead. Potti (1993) showed that the white forehead patch is expressed by female pied flycatchers in southern populations, where it seems to be used by females in mate choice (Potti \& Montalvo $199 \mathrm{l} a$ ). Furthermore, evidence suggests that the size of the forehead patch is highly heritable in males (around 40\%; Potti 1993; J. Potti \& S. Merino, unpublished data), and may be genetically correlated between the sexes. Interestingly, in the only other flycatcher races and/or species (i.e. including subspecies of hypoleuca and the monotypic $F$. albicollis, as well as $F$. semitorquata; see Lundberg \& Alatalo 1992; Mild 1994) for which sexual selection related to the white forehead patch in males seems to have been examined, Gustafsson et al. (1995) have cited unpublished evidence that the size of the male's white patch in collared flycatchers may also be implicated in sexual selection.

Apart from Møller's (1990b) experimental work pointing to the existence of a genetic correlation between resistance to ectoparasitic mites and expression of a secondary sexual trait in swallows (Hirundo rustica), the evidence for indirect fitness benefits in parasite-mediated sexual selection in wild populations is sparse (Møller \& Saino 1994). In this paper we examine the relations between infection by trypanosomes and the expression of the white frontal patch in both male and female pied flycatchers. Whereas all males express a white patch of variable size during the breeding season after the first prenuptial moult, a generally smaller white patch is expressed by only a 
fraction of females, in particular those aged two years or older. Interestingly in the context of the dimorphic plumage trait analysed in this paper, a recent comparative analysis of the Hamilton-Zuk hypothesis controlling for a large number of potentially confounding influences (phylogeny, scoring of plumage brightness, parasite prevalence, latitude, habitat, nesting habits, diet, foraging mode, mating system), showed that the intensity of parasite-driven sexual selection was more related to 'front' than 'back' brightness of plumage in Neartic birds, although female or bisexual brightness were not addressed (John 1995). Trypanosomes are a diverse and successful array of blood parasites (Peirce 1981; Kirkpatrick \& Suthers 1988; Bennett et al. 1995) although, contrary to their well-known detrimental effects on mammals (Olsen 1974), their effects on avian fitness have not been thoroughly explored (Apanius 1991; Rätti et al. 1993; Merino et al. 1996). After controlling for confounding factors relevant to Hamilton \& Zuk's prediction at the intraspecific level (Thomas et al. 1995), we show the possibility of an intricate route to parasite-driven sexual selection by mutual mate choice based on a secondary sexual trait and resistance to blood parasitism.

\section{METHODS}

We studied pied flycatchers and blood trypanosomes during the breeding seasons of 1993 and 1994 in a population in central Spain (Potti \& Merino 1994, 1995). Females were captured while incubating and males while feeding nestlings around the 7 th day after hatching. All birds were individually marked and aged as yearlings or older (Karlsson et al. 1986; Potti \& Montalvo 1991 a). Immigrant birds aged as adults at first capture were given a minimum age of 2 years (Potti \& Montalvo $1991 b$ ). For the analyses of infection intensity in relation to age, birds were grouped above 4-years-of-age to increase sample sizes of older birds. The length and breadth of the white forehead patch was measured with callipers to the nearest $0.05 \mathrm{~mm}$, and its size was calculated as the area of a rectangle. Data on white patch dimensions and size could only be taken in a fraction of females, as many of them do not express a white patch at all (Potti 1993).

A drop of blood was obtained from the brachial vein of males and females to assess the levels of infection by trypanosomes (Merino \& Potti 1995; Merino et al. 1996). Smears were air-dried, fixed in absolute ethanol and stained with Giemsa stain. For each bird, half a slide was examined under $\times 200$ objective in search of large extraerythrocytic hematozoa (i.e. trypanosomes). To prevent that the symmetry of the blood smear might cause a non-random distribution of parasites (Godfray et al. 1987) half a smear was entirely scanned. This entailed that in most cases more than 300 fields were scanned. Infection intensity was quantified as number of trypanosomes per 100 fields (Merino \& Potti 1995)

The distribution of trypanosomes was aggregated, and transformations did not improve the fit of the data to normal distributions, hence non-parametric statistics were used in the analyses of infection intensity (see Margolis et al. 1982). To investigate the variation of trypanosome infection with host age and white patch expression, as well as the possibility of interactions among different combinations of both ages and trait expression between pair mates, we did log-linear analysis (Sokal \& Rohlf 1981). This procedure is analogous to an analysis of variance in that total variance of frequency data is partitioned into different factors, making possible the testing of interactions between them. We ran the tests hierarchically beginning with the highest order interaction, so that dropping a significant $(p<0.05)$ term would result in a significant lack of fit of the model.

\section{RESULTS}

There were no differences between the sexes in trypanosome prevalence (males: 23.1\%, $n=195$; females: $25.9 \%, n=220 ; \chi^{2}=0.05, p=0.82$ ). Although females scored higher than males, average infection intensities did not differ between the sexes (males: $0.9 \pm$ s.e. $0.9, n=45$; females $1.2 \pm$ s.e. $1.6, n=$ 57; Mann-Whitney test, $Z=0.78, p=0.44$ ).

The intensity of trypanosome infection gradually decreased with advancing age in females from an average of 0.5 trypanosomes when they were yearlings to 0.11 when aged four or more years (see figure 1 ; Spearman rank correlation $r_{\mathrm{s}}=-0.36, p=0.0062$, $n=57$ ). The same trend between successive years was true within individual females (Wilcoxon's test for matched pairs, $Z=1.96, p=0.049, n=17$ females infected in both years). On the contrary, the intensity of infection by trypanosomes was unrelated to male age $\left(r_{\mathrm{s}}=0.11, p=0.46, n=46\right.$; figure 1). Similarly, there was no trend for an increase or decrease of infection intensity within individual males, although only two males were scored as infected in both years $(Z=0.71$, $p=0.48$ )

Size of the male white patch was unrelated to the intensity of trypanosome infection $\left(r_{\mathrm{s}}=0.11, p=0.51\right.$, $n=40$; figure $2 a)$. The same was true for females $\left(r_{\mathrm{s}}=\right.$ $0.44, p=0.24, n=8$ ). However, irrespective of white patch size, females expressing a white patch had a lower probability of being infected by trypanosomes $(11.8 \%)$ than those who did not express one $(33.3 \%$; $\left.\chi^{2}=10.2, n=190, p=0.001\right)$. This trend was not confounded by the covariation of female age with the expression of a white patch: a log-linear analysis of frequencies showed that the expression of the white patch in females was independently linked to both an older age and a lower probability of being infected by (a)

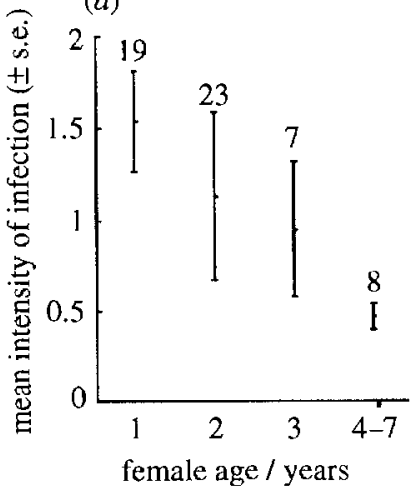

(b)

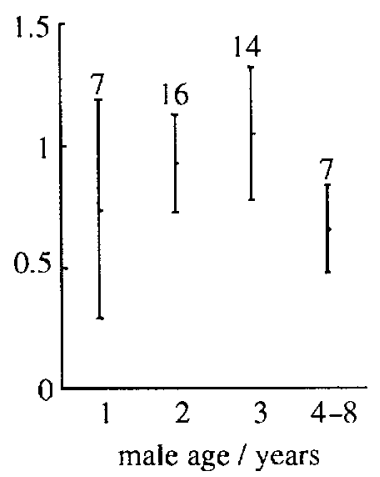

Figure 1. Relation between intensity of trypanosome infection with age in: (a) female and (b) male pied flycatchers. Infection intensity was quantified as number of trypanosomes per 100 fields; numbers above bars are sample sizes. Note different scales for males and females. 
(a)

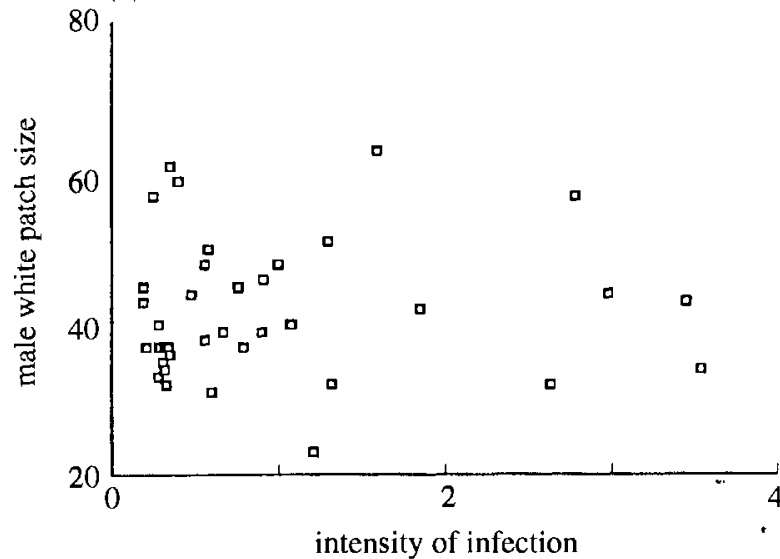

(b)

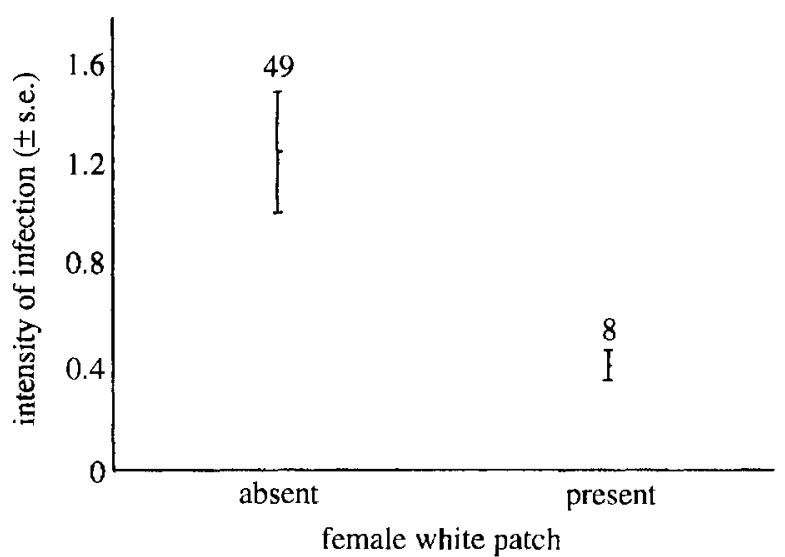

Figure 2. Intensity of trypanosome infections in relation to size ( $(a)$ males) and expression ( $(b)$ females $)$ of the white forehead patch in pied flycatchers. Numbers above bars are sample sizes.

Table 1. Loglinear analysis of female age, female white patch expression and trypanosome prevalence

\begin{tabular}{llrl}
\hline effect & d.f. & \multicolumn{1}{l}{$G$} & \multicolumn{1}{l}{$p$} \\
\hline female age $\times$ white patch $\times$ infection & 2 & 1.96 & 0.3746 \\
female age $\times$ infection & 1 & 12.16 & 0.0005 \\
female age $\times$ white patch & 1 & 29.18 & 0 \\
\hline
\end{tabular}

Table 2. Loglinear analysis of female white patch expression (fwp) in relation to female age, male age and male white patch size (mwps; the distribution of white patch size in males was categorised into four classes delimited by the quartiles of the size distribution)

(Goodness-of-fit test statistic for model adequacy: $G=12.5$, d.f. $=13, p=0.49$.

\begin{tabular}{|c|c|c|c|}
\hline effect & d.f. & $G$ & $p$ \\
\hline fwp $\times$ male age $\times$ mwps & 3 & 9.11 & 0.013 \\
\hline female age $\times$ male age & 1 & 7.96 & 0.005 \\
\hline fwp $\times$ female age & 1 & 17.16 & 0 \\
\hline
\end{tabular}

trypanosomes (see table 1). Also, the few infected females who expressed a white patch had a lower intensity of trypanosome infection (mean $0.42 \pm$ s.e. $0.16, n=9$ ) than females who did not express a white patch $(1.27 \pm$ s.e. $1.71, n=49$; Mann-Whitney test, $Z$ $=2.14, p=0.033$; figure $2 b)$. That is, females were less likely to be infected or to have high intensities of infection if they were old and, independently, if they expressed a white patch. None of the three females independently aged as yearlings that expressed a white patch was infected by trypanosomes.

Following the development of infection and expression of a white patch in individual females across successive years revealed that 14 females acquired a white patch in the second year while not being infected in either of the two study years; seven females expressed the white patch in both years while maintaining their infected status; four females developed infections in the second year but did not express a white patch; lastly, 12 females neither developed a white patch nor were apparently infected.
Mating was not random in relation to white patch size (males) or expression (females): when patch size of males was categorised into four groups based on the quartiles of white patch size distribution a significant interaction between male age, female expression of the white patch, and male white patch classes was found (see table 2). Males and females mated assortatively with respect to age but, independently, females expressing white patches were more likely to be paired with older males possessing the largest forehead patches than females not expressing the patch (three-way interaction, $G=17.16, p<0.001)$. At a quantitative level, although there was no correlation between patch size or length of pair mates, $(r=0.12$ and 0.08 , respectively; $n=53, p>0.37$ in both cases) there was positive assortative mating with respect to patch breadth ( $r=0.3, n=53, p=0.029$ ).

\section{DISCUSSION}

We have shown that levels of infection by trypanosomes decrease with advancing age in female pied flycatchers and are independently linked to the expression of a correlated secondary sexual trait. On the contrary, infection levels were unrelated to male age or to the size of the white patch in males, a preferred sexual character in this population. Although Hamilton \& Zuk's (1982) hypothesis has been usually recast in terms of male rather than female or bisexual brightnesss, their original analysis included a bisexual brightness correlation with parasite prevalence. Hence, although female mate choice was apparently unrelated to trypanosome resistance in our population (i.e. female flycatchers should apparently be unable to assess the resistance of males to trypanosomes by using the development of male sexual traits), we argue that our results are not at variance with the prediction that plumage brightness and resistance to parasites are coevolving. Instead, our results are consistent with the Hamilton-Zuk prediction, in particular when they are interpreted in terms of mutual mate choice (Jones \& Hunter 1993) for 'good genes' (reviewed by Andersson 1994; Møller 1994; Johnstone 1995): males that mate with females that express a white patch are choosing 
old females with a lower likelihood of being infected by trypanosomes. Furthermore, in addition to these indirect benefits for individual fitness, direct benefits accrued to males from mating with old, brightly coloured and uninfected females are an advanced laying date (Berndt \& Winkel 1967; Lundberg \& Alatalo 1992) conferring a higher chance of recruiting to the breeding population (Potti \& Montalvo $1991 b$; Potti \& Merino 1994). More direct benefits accrued to female fitness from mating with a male displaying a large forehead patch are an increased weight and condition of the offspring (J. Potti \& S. Merino, unpublished data) while the indirect benefits should be similar to those enjoyed by males. Finally, by mating with females who carry genes for the expression of large white patches in their male offspring (Potti 1993) the males would sire sons with higher than average mating success in the adulthood (Potti \& Montalvo 1991a), i.e. the direct benefit of having sexy sons (Weatherhead \& Robertson 1979) might also be at work.

The relations here presented between the expression of a sexual secondary trait by females and associated lower trypanosome infections open the possibility of honest signalling by the expression of this trait in females, a possibility usually envisaged only for males (Folstad \& Karter 1992; Andersson 1994; Møller \& Saino 1994). Although the effects of trypanosomes on both adult birds and their offspring (Merino et al. 1996) are far from clear, there exists some evidence on detrimental effects in our population, as trypanosomes are known to delay breeding onset independently of female age (J. Potti \& S. Merino, unpublished data; see also Rätti et al. 1993; Dufva 1994) and experimental evidence is accumulating that other common avian parasitic protozoa have detrimental effects on avian host fitness (Richner et al. 1993; Norris et al. 1994). Coupling of parasite resistance and expression of sexual traits may indicate that only those females that express the male trait can maintain their infections under control and have high levels of circulating sexual hormones (Folstad \& Karter 1992; Saino \& Møller 1994), i.e. they would be honestly signalling quality (parasite resistance and/or high immunocompetence). The white patch is normally expressed by female pied flycatchers in this population only after the age of two years (Potti 1993; this study). However, a small number of females express a white patch when they are one-year-old. Interestingly, the three females who expressed a white patch when they were yearlings were uninfected by trypanosomes, and all the four older females that did not develop a white patch in the second year of study were infected the previous year. Although circumstantial, the available evidence within females also suggests that parasitism by trypanosomes may act as a constraint on the expression of this trait.

The absence of any relation in our study between prevalence or intensity of trypanosome infection and white patch size in males as opposed to the case for male-looking females is at least surprising. The fact that all males express a white patch in southern European populations while only some females do seems to indicate that this trait may have been subjected to a longer (and stronger) history of selection in males. If so, this could conceivably be reflected in a more canalized regulation of white patch expression in males which, from the crucial point of pairing, have 'to make the best of the bad job' of wearing immunocompetence-reducing ornaments (Folstad \& Karter 1992; see also below), as no female-like males (type VII in Drost's (1936) scale) exist in Spanish populations, contrary to pied flycatchers in other European populations (see, for examples, Slagsvold \& Sœtre 1991; Sætre et al. 1992; Sætre 1993). On the contrary, female pied flycatchers have been experimentally shown to be recognized as such by males and females independently of its expression of a white patch (Scetre \& Slagsvold 1992), i.e. while forming the badge may be a priority for males it may pay to females to express the trait only in some circumstances. However, we think that solid ultimate explanations for the development of correlated plumage sexual traits should draw on existing knowledge on the operation of proximate mechanisms. Unfortunately, these are presently unclear, even regarding something so essential as the types of biochemicals involved in plumage sexual dimorphisms, as we discuss below.

The essence of Folstad \& Karter's (1992) immunocompetence handicap model is the interference between parasites, sexual hormones and the immune system affecting the expression of secondary sexual traits (see also Alexander \& Stimson 1989; Zuk 1990; Wedekind \& Folstad 1994). The immunocompetence handicap theory was developed with a focus on male secondary sexual traits, and no predictions were made concerning the expression of correlated sexual traits in females. The handicapping mechanism assures that one of the cause-effect routes derived from the model's structure, i.e. that connecting expression of costly sexual traits to circulating levels of androgens and immunosuppression, can be only circumvented by high-quality individuals. If the handicapping mechanism were not at work, were the expression of sexual traits in females be related to circulating levels of androgens also in this gender, females expressing male traits would be immunocompromised when challenged by trypanosome infections, therefore showing higher levels of infection than females not expressing these traits. In fact, the opposite result was found in this study which, in addition to casting doubt on the premise that androgens determine the expression in females of male sexual traits, indicates that some other mechanisms is operating. Furthermore, the assumption that showy male plumages are testosterone-dependent has been challenged by Owens \& Short $(1995 a, b)$, who have convincingly argued that absence of oestrogens, rather than presence of testosterone may be involved in many plumage dimorphisms (see also SivaJothy 1995; Møller 1995). Following Fostad \& Karter (1992), and if Owens \& Short (1995a) are right so that the white patch of female pied flycatchers were determined by absence of oestrogens, then females expressing a patch should have high immunocompetence and a decreased parasite intensity, as observed. But Folstad \& Karter's handicapping model should also predict that, irrespective of the type of biochemical involved in plumage dimorphisms (Møller 
\& Saino 1994; Wedekind \& Folstad 1994; Møller 1995; Owens \& Short 1995b), pied flycatcher females that are uninfected by trypanosomes or have recently eliminated an infection might allow themselves a lower immune response and hence higher levels of the relevant circulating steroids for displaying a white patch. Another possibility is that the females that express the white patch were not confronted by trypanosomes before, or that they were able to elimimate the infection sometime ago and now may express high levels of hormone. These possibilities should be examined and, ideally, experimentally tested more thoroughly in avian species (in addition to pied flycatchers, e.g. red-winged blackbirds, Agelaius phoenieceus (Muma \& Weatherhead 1989); lesser kestrels (Falco naumanni) (Tella et al. 1996)) which, from the endochrinological approach embedded in the immunocompetence handicap model, potentially offer the best of both worlds by showing correlated traits between the sexes.

We thank Mario Herrera and Juan Moreno for help in the field and J. L. Tella for access to unpublished manuscripts. One reviewer made constructive and imaginative suggestions to a first draft which are gratefully acknowledged. Our work was supported by the Spanish DGICYT (projects PB910084-C03-03 and PB94-0070-C02-02) and by a PFPI grant of the Comunidad de Madrid to S.M.

\section{REFERENGES}

Alexander, J. \& Stimson, W. H. 1989 Sex hormones and the course of parasitic infection. Parasit. Today 4, 1891-1893.

Andersson, M. 1994 Sexual selection. Princeton University Press.

Apanius, V. 1991 Avian trypanosomes as models of hemoflagellate evolution. Parasit. Today 7, 87-90.

Bennett, G. F., Squires-Parsons, D., Siikamäki, P. Huhta, E., Allander, K. \& Hillström, L. 1995 A comparison of the blood parasites of three Fenno-Scandian populations of the pied flycatcher Ficedula hypoleuca. J. Avian Biol. 26, 33-38.

Berndt, R. \& Winkel, W. 1967 Die Gelegegrösse des Trauerschnäppers (Ficedula hypoleuca) in Beziehung zu Ort, Zeit, Biotop und Alter. Vogelwelt 88, 97-136.

Cramp, S. \& Perrins, C. M. 1993 The birds of the western Palearctic, vol. VII. Oxford University Press.

Drost, R. 1936 Über das Brutkleid männlicher Trauerfliegenfänger, Muscicapa hypoleuca. Vogelzug 6, 179-186.

Dufva, R. 1994 Effects of blood parasites on egg size in two bird species. Int. Behav. Ecol. Congr. (Nottingham), Abstract no. 51 .

Dufva, R. \& Allander, K. 1995 Intraspecific variation in plumage coloration reflects immune response in great tit (Parus major) males. Funct. Ecol. 9, 785-789.

Folstad, I. \& Karter, A. J. 1992 Parasites, bright males, and the immunocompetence handicap. Am. Nat. 139, 603-622.

Godfray, R. D., Fedynich, A. M. \& Pence, D. B. 1987 Quantification of hematozoa in blood smears. J. Wildl. Dis. 23, 558-565.

Gustafsson, L., Qvarnström, A. \& Sheldon, B. C. 1995 Trade-offs between life-history traits and a secondary sexual character in male collared flycatchers. Nature, Lond. $375,311-313$.

Hamilton, W. D. \& Zuk, M. 1982 Heritable true fitness and bright birds: a role for parasites? Science, New York 218, $284-287$.
Hill, G. E. 1992 Proximate basis of variation in carotenoid pigmentation in male house finches. $A u k 109,1-12$.

Järvi, T., Røskaft, E., Bakken, M. \& Zumsteg, B. 1987 Evolution of variation in male secondary sexual characteristics. A test of eight hypotheses applied to pied flycatchers. Behav. Ecol. Sociobiol. 20, 161-169.

John, J. L. 1995 Hematozoan parasites, mating systems and colourful plumages in songbirds. Oikos 72, 395-401.

Johnstone, R. A. 1995 Sexual selection, honest advertisement and the handicap principle: reviewing the evidence. Biol. Rev. 70, 1-65.

Jones, I. L. \& Hunter, F. M. 1993 Mutual sexual selection in a monogamous seabird. Nature, Lond. 362, 238-239.

Kirkpatrick, C. E. \& Suthers, H. B. 1988 Epizootiology of blood parasite infections in passerine birds from central New Jersey. Can. J. Zool. 66, 2374-2382.

Lundberg, A. \& Alatalo, R. V. 1992 The pied flycatcher. London: Poyser.

Margolis, L., Esch, G. W., Holmes, J. C., Kuris, A. N. \& Schad, G. A. 1982 The use of ecological terms in parasitology (report of an ad hoc committee of the American Society of Parasitologists). J. Parasit. 68, 131-133.

Merino, S. \& Potti, J. 1995 High prevalence of trypanosomes in nestlings of a passerine bird, the pied flycatcher Ficedula hypoleuca. Auk 112, 1041-1043.

Merino, S., Potti, J. \& Moreno, J. 1996 Maternal effort mediates the prevalence of trypanosomes in the offspring of a passerine bird. Proc. natn. Acad. Sci. U.S.A. 93, 5726-5730.

Mild, K. 1994 Field identification of pied, collared and semi-collared flycatchers. Part 1: males in breeding plumage. Birding World 7, 139-151.

Møller, A. P. 1990 a Parasites and sexual selection: current status of the Hamilton and Zuk hypothesis. J. evol. Biol. 3, 319-328.

Møller, A. P. $1990 b$ Effects of an haematophagous mite on the barn swallow (Hirundo rustica) : a test of the Hamilton and Zuk hypothesis. Evolution 44, 771-784.

Moller, A. P. 1994 Sexual selection and the barn swallow. Oxford University Press.

Møller, A. P. 1995 Hormones, handicaps and bright birds. Trends Ecol. Evol. 10, 121.

Møller, A. P. \& Saino, N. 1994 Parasites, immunology of hosts, and host sexual selection. J. Parasit. 80, 850-858.

Muma, K. E. \& Weatherhead, P.J. 1989 Male traits expressed in females: direct or indirect sexual selection? Behav. Ecol. Sociobiol. 25, 23-31.

Norris, K., Anwar, M. \& Read, A. F. 1994 Reproductive effort influences the prevalence of haematozoan parasites in great tits. J. Anim. Ecol. 63, 601-610.

Olsen, O. W. 1974 Animal parasites. Their life cycle and ecology. Baltimore: University Park Press.

Owens, I. P. F. \& Short, R. V. 1995 a Hormonal basis of sexual dimorphism in birds: implications for new theories of sexual selection. Trends Ecol. Evol. 10, 44-47.

Owens, I. P. F. \& Short, R. V. 1995 b Hormones, handicaps and bright birds. Reply to A. P. Møller. Trends Ecol. Evol. 10, $121-122$.

Peirce, M. A. 1981 Distribution and host-parasite check-list of the haematozoa of birds in Western Europe. J. nat. Hist. 15, 419-458.

Potti, J. 1993 A male trait expressed in female pied flycatchers Ficedula hypoleuca: the white forehead patch. Anim. Behav. 45, 1245-1247.

Potti, J. \& Merino, S. 1994 Heritability estimates and maternal effects on tarsus length in pied flycatchers, Ficedula hypoleuca. Oecologia 100, 331-338.

Potti, J. \& Merino, S. 1995 Louse loads of pied flycatchers: 
effects of host's sex, age, condition and relatedness. J. Avian Biol. 26, 203-208.

Potti, J. \& Montalvo, S. 1991 a Male arrival and female mate choice in pied flycatchers Ficedula hypoleuca in central Spain. Ornis Scand. 22, 45-54.

Potti, J. \& Montalvo, S. $1991 b$ Return rate, age at first breeding and natal dispersal of pied flycatchers Ficedula hypoleuca in Central Spain. Ardea 79, 449-458.

Potti, J. \& Montalvo, S. $1991 c$ Male colour variation in Spanish pied flycatchers Ficedula hypoleuca. Ibis 133, 293-299.

Rätti, O., Dufva, R. \& Alatalo, R. V. 1993 Blood parasites and male fitness in the pied flycatcher. Oecologia 96, $410-414$

Read, A. F. 1988 Sexual selection and the role of parasites. Trends Ecol. Evol. 3, 97-101.

Richner, H. A., Christe, P. \& Oppliger, A. 1995 Paternal investment affects prevalence of malaria. Proc. natn. Acad. Sci. U.S.A. 92, 1192-1194.

Røskaft, E. \& Järvi, T. 1983 Male plumage colour and mate choice of female pied flycatchers Ficedula hypoleuca. Ibis 125, 396-400.

Sætre, G.-P., Kràl, M. \& Bicik, V. 1992 Experimental evidence for interspecific female mimicry in sympatric Ficedula flycatchers. Evolution 47, 939-945.

Sxtre, G.-P. 1993 Sex recognition by male pied flycatchers in a population with little sexual dimorphism in plumage colour. Ornis Scand. 24, 158-160.

Sxtre, G.-P. \& Slagsvold, T. 1992 Evidence for sex recognition from plumage colour by the pied flycatcher, Ficedula hypoleuca. Anim. Behav. 44, 293-300.

Sætre, G.-P., Dale, S. \& Slagsvold, T. 1994 Female pied flycatchers prefer bright coloured males. Anim. Behav. 4, 1407-1416.

Saino, N. \& Møller, A. P. 1994 Secondary sexual characters, parasites and testosterone in the barn swallow, Hirundo rustica. Anim. Behav. 48, 1325-1333.
Savalli, U. M. 1995 The evolution of bird coloration and plumage elaboration. In Current ornithology, vol. 12 (ed. D. M. Power), pp. 141-190. New York: Plenum Press.

Seutin, G. 1994 Plumage redness in redpoll finches does not reflect hemoparasitic infection. Oikos 70, 280-286.

Siva-Jothy, M. T. 1995 'Immunocompetence': conspicuous by its absence. Trends Ecol. Evol. 10, 205-206.

Slagsvold, T. \& Lifjeld, J. T. 1988 Plumage colour and sexual selection in the pied flycatcher Ficedula hypoleuca. Anim. Behav. 36, 395-407.

Slagsvold, T. \& Sitre, G.-P. 1991 Evolution of plumage colour in male pied flycatchers (Ficedula hypoleuca): evidence for female mimicry. Evolution 45, 910-917.

Sokal, R. R. \& Rohlf, F.J. 1981 Biometry, 2nd edn. San Francisco: Freeman.

Sundberg, J. 1995 Parasites, plumage coloration and reproductive success in the yellowhammer Emberiza citrinella. Oikos 74, 331-339.

Tella, J. L., Forero, M. G,, Donázar, J. A. \& Hiraldo, F. 1996 Is the expression of male traits in female lesser kestrels related to sexual selection? Ethology (In the press.)

Thomas, F., Renaud, F., De Meeüs, T. \& Cézilly, F. 1995 Parasites, age and the Hamilton-Zuk hypothesis: inferential fallacy? Oikos 74, 305-309.

Weatherhead, P. J. 1990 Secondary sexual traits, parasites, and polygyny in red-winged blackbirds, Agelaius phoeniceus. Behav. Ecol. 1, 125-130.

Weatherhead, P.J. \& Robertson, R.J. 1979 Offspring quality and the polygyny threshold: 'The sexy son hypothesis'. Am. Nat. 113, 201-208.

Wedekind, C. \& Folstad, I. 1994 Adaptive or non-adaptive immunosuppression by sex hormones? Am. Nat. 143, 936-938.

Zuk, M. 1990 Reproductive strategies and sex differences in disease susceptibility: an evolutionary viewpoint. Parasit. Today 6, 231-233.

Received 11 April 1996; accepted 4 June 1996 